This journal is the official publication of Bangladesh Society of Physiologists (BSP)

Web URL: www.banglajol.info/index.php/JBSP

Abstracted /indexed in Index Copernicus, Director of Open Access Journal, HINARI Index Medicus for South East Asia Region, Google Scholar, 12OR, infobse index, Open J gate, Cite factor, Scientific indexing services

pISSN-1983-1213; e-ISSN-2219-7508

\title{
Article
}

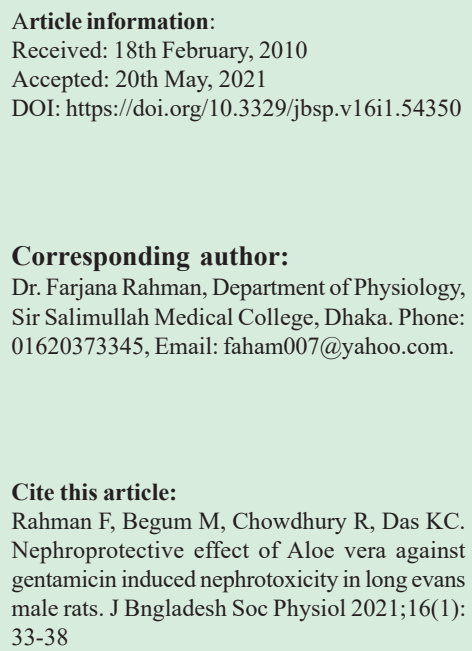

This article is open access licensed under CC BY NC SA which allows readers copy, distribute, display, and perform the work and make derivative works based on it only for noncommercial purposes.

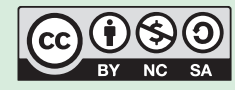

\section{Nephroprotective effect of Aloe barbadensis Miller against gentamicin induced nephrotoxicity in long evans male rats}

\author{
Farjana Rahman', Mahmuda Begum¹, Rama \\ Chowdhury ${ }^{1}$ \\ 1. Department of Physiology, Sir Salimullah Medical College, Dhaka.
}

\section{Abstract}

Background: Kidney is an essential excretory organ of our body. It can be damaged by poisonous effect of chemicals, toxin, prolonged and uncontrolled use of drugs. Aloe vera is a herbal plant, it can be used for the prevention and treatment of kidney damage due to its natural compatability. Objective: To observe the nephroprotective effect of Aloe vera against gentamicin induced nephrotoxicity in long evans male rats. Method: This experimental study was conducted in the Department of Physiology, Sir Salimullah Medical College (SSMC), Dhaka from $1^{\text {st }}$ January 2018 to $30^{\text {th }}$ December 2018 . For this, forty five (45) apparently healthy long evans male rats, 90-120 days old, weighing between 150-200 g were taken and divided into control group (group A) and experimental group (group B - Aloe vera pretreated and gentamicin treated group). Control group was subdivided into group $\mathrm{A}_{1}$ (baseline control group) and group $\mathrm{A}_{2}$ (gentamicin treated control group). Each group consisted of fifteen (15) rats. At the beginning of the study period initial body weight of rats were measured at day 01 . All the rats received basal diet for thirty (30) days. Group $A_{1}$ received only basal diet for 30 consecutive days (started from day 1 to day 30 ). In addition to basal diet, group $\mathrm{A}_{2}$ received injection gentamicin intraperitoneally once daily in the morning ( $80 \mathrm{mg} / \mathrm{kg} /$ day $)$ for last 5 days $\left(26^{\text {th }}\right.$ to $\left.30^{\text {th }}\right)$ of the study period. Again, in addition to basal diet, experimental group received Aloe vera orally (200 $\mathrm{mg} / \mathrm{kg} /$ day) for 30 days and injection gentamicin 
intraperitoneally ( $80 \mathrm{mg} / \mathrm{kg} /$ day) for last 5 days $\left(26^{\text {th }}\right.$ to $\left.30^{\text {th }}\right)$. After measuring final body weight all the rats were sacrificed on day 31. Blood sample was collected from heart. Serum levels of creatinine and urea were estimated for assessment of kidney function. Statistical analysis was done by one way ANOVA test followed by post hoc-Bonferroni test. Result: Mean serum levels of creatinine and urea were significantly $(\mathrm{p}<0.001)$ higher in gentamicin treated control group in comparison to that of base line control group. Again these levels were significantly $(p<0.001)$ lower in Aloe vera pretreated and gentamicin treated group than that of gentamicin treated control group. Conclusion: From this study, it is concluded that Aloe vera has nephroprotective effect against gentamicin induced nephrotoxicity.

Key words: Aloe vera, Nephroprotective, Gentamicin.

\section{Introduction}

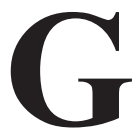
entamicin is an aminoglycoside widely used in the clinical practice for the treatment of both gram-negative and gram-positive bacterial infections. It is used in the treatment of septicaemia, sepsis, bacterial endocardities, etc. Its main side effects are ototoxicity, neuromuscular blockade and toxic renal damage ${ }^{1}$. So, nephrotoxicity is one of the common side effect for patient receiving gentamicin ${ }^{2}$.

Now a days, different herbal plant products show good prospect to overcome such unwanted side effects. Several experimental studies with plant products such as Nigella sativa ${ }^{3}$, curcumin $^{4}$, honey ${ }^{5}$, gum Arabic ${ }^{6}$ have used for preventing and treating gentamicin induced nephrotoxicity.

Aloe vera (Aloe barbadensis Miller) is a herbal plant which is cheap, easily available and safe. It has several biologically active substances such as polpyphenols, indoles and alkaloids ${ }^{7}$. This herb has various medicinal properties such as anti-inflammatory ${ }^{8}$, antidiabetic ${ }^{9}$, antioxidant ${ }^{10}$, and hepatoprotective effects ${ }^{11}$.
Again, this medicinal plant extract was shown to decrease serum urea and creatinine levels in rat models of gentamicin induced nephrotoxicity ${ }^{12}$. Moreover serum urea and creatinine levels were found significantly lower in gentamicin induced nephrotoxic rats with 7 days Aloe vera treatment in comparison to those of without Aloe vera treated rats ${ }^{13}$.

However, as far as it has been searched, no reported data regarding prevention of gentamicin induced nephrotoxicity by Aloe vera was available in our country. On the basis of this background, this study has been designed to evaluate the nephroprotective role of Aloe vera against gentamicin induced nephrotoxicity in long evans male rats.

\section{Methods}

This experimental study was conducted from $1^{\text {st }}$ January to $30^{\text {th }}$ December 2018 in the Department of Physiology, Sir Salimullah Medical College, Dhaka. Ethical permission was taken before conducting the study from Institutional Ethics Committee (IEC) of Sir Salimullah Medical College (SSMC), Dhaka. 
Procurement and maintenance: A total number of forty five (45) apparently healthy long evans male rats, 90-120 days old, weighing between 150-200 $\mathrm{g}$ were purchased from animal house of Department of Pharmacology, BSMMU and the rats were kept in the animal house of Institute of Nutrition and Food Science, University of Dhaka. All the rats were acclimatized for 14 days prior to intervention at $23 \pm 2{ }^{\circ} \mathrm{C}$ room temperature under 12 hours dark-light cycle. During this period, the animals had free access to food and water ad libitum. At the beginning of the study period (day-1) initial body weight of rats were measured.

\section{Grouping and dose schedule}

All the rats were divided into two groups, control group (group A) and experimental group (group B - Aloe vera pretreated and gentamicin treated group). Control group is subdivided into group $A_{1}$ (baseline control group) and group $A_{2}$ (gentamicin treated control group). Each group consisted of fifteen (15) rats. All the rats received basal diet for thirty (30) days. Group $\mathrm{A}_{1}$ received only basal diet for 30 consecutive days (started from day 1 to day 30 ).

In addition to basal diet, group $\mathrm{A}_{2}$ received injection gentamicin intraperitoneally once daily in the morning $(80 \mathrm{mg} / \mathrm{kg} /$ day $)$ for last 5 days ( $26^{\text {th }}$ to $30^{\text {th }}$ ) of the study period. Again, in addition to basal diet experimental group received Aloe vera orally (200 $\mathrm{mg} / \mathrm{kg} /$ day) for 30 days and injection gentamicin intraperitoneally ( $80 \mathrm{mg} / \mathrm{kg} /$ day) for last 5 days $\left(26^{\text {th }}\right.$ to $\left.30^{\text {th }}\right)$.

Preparation of ethanolic extract of Aloe vera: ${ }^{14}$ Aloe vera leaves washed with water, then parenchymatous covering of the leaves were peeled and gel drained out. Then the gel was dried in an air-oven. The dried sample was crushed into powder with an electrical grinder. Then ethanolic extract of aloe vera gel extract was prepared. The concentrated extract was dissolved in distilled water for administration to rats.

Blood collection: On the day 31, at the end of the study period, after measuring the final body weight, all the rats were anaesthetized with the help of chloroform (30\%) and were sacrificed. Blood sample $(2 \mathrm{ml})$ were collected from heart. Then blood was centrifuged and supernatant serum was collected and preserved in the refrigerator for biochemical analysis. Serum creatinine and serum urea levels were estimated for assessment of kidney function. Serum levels of creatinine and urea were estimated by fixed time kinetic method ${ }^{15}$ and enzymatic colorimetric method $^{16}$ respectively.

\section{Statistical analysis}

All the data were expressed as mean \pm SD. Statistical analysis were done by using one way ANOVA followed by post hoc-Bonferroni test. $\mathrm{p}<0.05$ was considered as level of significance.

\section{Results}

Percent (\%) change of body weight from final to initial was significantly $(\mathrm{p}<0.001)$ lower in group $A_{2}$ than that of group $A_{1}$. Again percent (\%) change of body weight was lower in group $B$ in comparison to that of group $A_{1}$. Whereas, it was higher in group $B$ than that of group $A_{2}$. But the differences were not statistically significant (Table I).

Again, the mean serum creatinine and urea levels were significantly ( $\mathrm{p}<0.001)$ higher in group $\mathrm{A}_{2}$ and group $\mathrm{B}$ in comparison to that of group $\mathrm{A}_{1}$. Whereas, these levels were significantly $(\mathrm{p}<0.001)$ lower in group $B$ than that of group

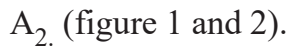


Table I: Initial and final body weight in different groups of rats $(\mathrm{N}=45)$

\begin{tabular}{|c|c|c|c|}
\hline \multirow[t]{2}{*}{ Group } & \multicolumn{2}{|c|}{ Body weight $(\mathrm{g})$} & \multirow{2}{*}{$\begin{array}{c}\% \text { of change from } \\
\text { final (F) to initial } \\
\text { (I) body weight } \\
{[(\mathrm{F}-\mathrm{I}) / \mathrm{Ix} 100]}\end{array}$} \\
\hline & Initial (I) & Final $(\mathrm{F})$ & \\
\hline \multirow[t]{2}{*}{$A_{1}(n=15)$} & $176.07 \pm 6.58$ & $211.87 \pm 7.76$ & $20.39 \pm 3.77$ \\
\hline & $(166-188)$ & $(200-228)$ & $(15.64-29.59)$ \\
\hline \multirow[t]{2}{*}{$\mathrm{A}_{2}(\mathrm{n}=15)$} & $177.27 \pm 5.80$ & $199.27 \pm 14.04$ & $12.33 \pm 5.60$ \\
\hline & $(168-189)$ & $(172-221)$ & $(2.38-21.02)$ \\
\hline B & $176.87 \pm 5.59$ & $205.80 \pm 8.48$ & $16.37 \pm 3.57$ \\
\hline$(n=15)$ & $(170-187)$ & $(195-218)$ & $(11.36-26.90)$ \\
\hline \multicolumn{4}{|c|}{ Statistical analysis } \\
\hline & Initial body & Final body & $\%$ of change \\
\hline & weight & weight & \\
\hline & $\mathrm{p}$ value & $\mathrm{p}$ value & $\mathrm{p}$ value \\
\hline$A_{1}$ vs $A_{2}$ vs $B$ & 0.857 & $0.008 *$ & $0.000^{* * *}$ \\
\hline $\mathrm{A}_{1}$ vs $\mathrm{A}_{2}$ & 1.000 & $0.006^{* *}$ & $0.000^{* * *}$ \\
\hline $\mathrm{A}_{1}$ vs $\mathrm{B}$ & 1.000 & 0.361 & 0.057 \\
\hline$A_{2}$ vs $B$ & 1.000 & 0.285 & 0.052 \\
\hline
\end{tabular}

Results are expressed as mean \pm SD. Statistical analysis was done by one way ANOVA test followed by post hoc-Bonferroni test. Figures in parentheses indicate ranges; Group $\mathrm{A}_{1}$ : Base line control group; Group $\mathrm{A}_{2}$ : Gentamicin treated control group; Group B: Aloe vera pre treated and gentamicin treated group; $\mathrm{N}=$ Total number of rats; $*=\mathrm{p}<0.05 ; * *=\mathrm{p}<0.01, * * *=\mathrm{p}<0.001$.

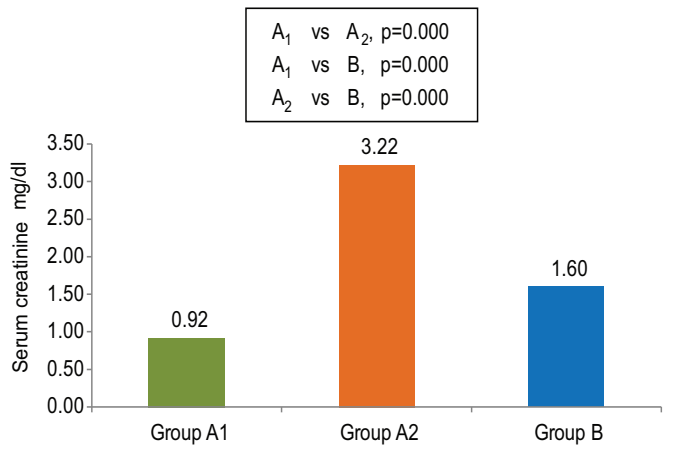

Figure 1: Mean serum creatinine level in different groups of rats. Group $\mathrm{A}_{1}$ : Base line control group; Group $\mathrm{A}_{2}$ : Gentamicin treated control group; Group B: Aloe vera pre treated and gentamicin treated group; Each bar symbolize for mean $\pm \mathrm{SD}$ for 15 rats. $* * *=p<0.000$ in $\mathrm{A}_{1 \mathrm{vs}} \mathrm{A}_{2} ; * * *=\mathrm{p}<$ 0.000 in $\mathrm{A}_{1 \text { vs }} \mathrm{B} ; * * *=\mathrm{p}<0.000$ in $\mathrm{A}_{2 \text { vs }} \mathrm{B}$.

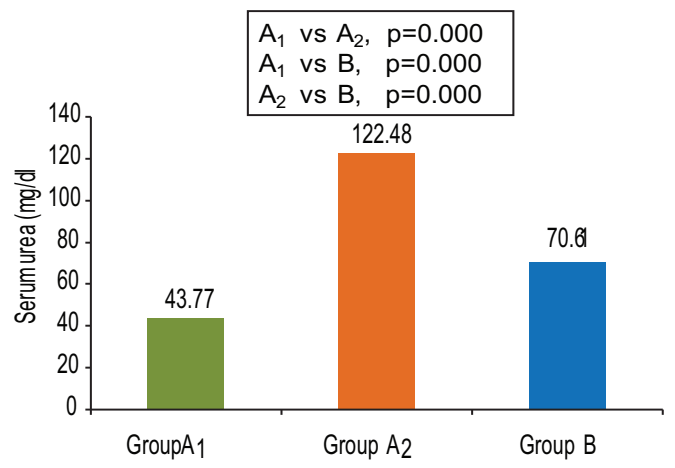

Figure 2: Mean serum urea level in different groups of rats. Group $\mathrm{A}_{1}$ : Base line control group; Group $\mathrm{A}_{2}$ : Gentamicin treated control group; Group B: Aloe vera pre treated and gentamicin treated group; Each bar symbolize for mean $\pm \mathrm{SD}$ for 15 rats. $* * *=p<0.000$ in $\mathrm{A}_{1 \text { vs }} \mathrm{A}_{2} ; * * *=\mathrm{p}<$ 0.000 in $A_{1 \text { vs }} B ; * * *=p<0.000$ in $A_{2 \text { vs }} B$. 
Discussion

In this study, mean serum creatinine and urea levels were estimated to assess renal function. Serum creatinine and urea levels were significantly higher in gentamicin treated group in comparison to those of baseline control group. These findings were similar to the findings reported by the various investigators from different countries 17,18, Gentamicin induced production of free radicals might cause lipid peroxidation followed by oxidative stress and subsequent renal damage ${ }^{19}$. Whereas, serum creatinine and urea levels were significantly lower in Aloe vera pretreated and gentamicin treated group than those of gentamicin treated control group. Different researchers found similar findings $s^{12,13}$.

Aloe vera prevented the gentamicine induced nephrotoxicity in experimental rats. Some investigators suggested that Aloe vera possesses antioxidants (polyphenols, indules, alkaloids, coumarin, vanillic acid) $7,10,20$. These antioxidant properties exhibit strong scavenging effect on different free radicals (superoxide, hydroxyl) ${ }^{10}$. They inhibit lipid peroxidation ${ }^{10}$ and increase superoxide dismutase, catalase enzymes activity and prevent free radical induced renal damage 9,10 .

In addition, percent change of body weight was significantly lower in gentamicin treated control group than that of baseline control group. This finding is similar to different studies ${ }^{18,21}$. Some researchers observed that this might be due to loss of appetite by gentamicin injection which results in decrease food intake and ultimately causes loss of body weight ${ }^{22}$.

In the present study renal damage was observed in rats treated with gentamicin as evidenced by their elevated levels of serum creatinine and urea.

Again lower levels of serum urea and creatinine were observed in rats of Aloe vera pre treated and gentamicin treated group.

The present study suggested that Aloe vera has nephroprotective role against gentamicin induced nephrotoxicity in rats. This effect is most likely may be due to antioxidant property of Aloe vera.

\section{Conclusion}

From the result of the study, it is concluded that, aloe vera has nephroprotective effect on gentamicin induced nephrotoxicity in long evans male rats.

\section{Conflict of interest: None}

\section{References}

1. Bennett PN, Brown MJ, Sharma P. Clinical Pharmacology. 11 th ed. London: Elsevier limited; 2012.

2. Deck DH, Pharma D, Winston LG. Aminoglycosides \& Spectinomycin. In: Katzung BG, editor. Basic \& Clinical Pharmacology. $13^{\text {th }}$ ed. New Delhi: McGraw Hill Education Private Limited; 2015. p. 803.

3. Begum NA, Dewan ZF, Nahar N, Mamun MIR. Effect of n-hexane extract of Nigella sativa on gentamicininduced nephrotoxicity in rats. Bangladesh $\mathrm{J}$ Pharmacol. 2006; 1: 16-20.

4. Bayomy MFF, EI-Naby SEH, Salem TA, Salem GM. Protective Role of Curcumin on Gentamicin Induced Renal Toxicity in Male albino rats. Egypt J Exp Biol. 2011; 7(1): 63-69.

5. Kalyan SC, Muglikar AG. Effect of honey on gentamicin induced nephrotoxicity in albino rats. Int J Pharma Bio Sci. 2012; 3(1): 459-464.

6. Ali BH, Al-Qarawi AA, Haroun EM, Mousa HM. The Effect of Treatment with Gum Arabic on Gentamicin Nephrotoxicity in Rats: A Preliminary Study. Renal Failure. 2003; 25(1): 15-20.

7. Nejatzadeh-Barandozi F. Antibacterial activities and antioxidant capacity of Aloe vera. Org Med Chem lett. 2013; 3: 1-13.

8. Vazquez B, Avila G, Segura D, Escalante B. Antiinflammatory activity of extract From Aloe vera gel. J Ethnopharmacol.1996; 55: 69-75.

9. Dangi NB, Gyanwali M, Gyanwali P, Sapkota HP, Pandey A, Shrestha A. Evaluation of Aloe vera Leaves Extract in Streptozotocin-Induced Diabetic Nephropathy in rat. J Chitwan Med Col. 2015; 5(14): 55-63.

10. Debnath T, Ghosh M, Lee YM, Deb Nath NC, Lee KG, Lim BO. Identification of phenolic constituents and 
antioxidant activity of Aloe barbadensis flower extracts. Food Agricul Immunol. 2017; 29(1): 1-12.

11. Jakkala LK, ALI SA. Aloe vera Protects the Aluminium Induced Degenerative Changes in liver and kidney of Albino rats, Rattus norvegicus. J Glob Biosci. 2015; 4(8): 3158-3164.

12. Virani S, Bhatt S, Saini M, Saxena KK. Aloe vera Attenuates Gentamicin-Induced Nephrotoxicity in Wister Albino Rats: histopathological and biochemical changes. Asian J Pharmaceut Clin Res. 2016; 9(1): 113-117.

13. Chatterjee P, Mukherjee A, Nandy S. Protective effects of the aqueous leaf extract of Aloe barbadensis on gentamicin and cisplatin-induced nephrotoxic rats. Asian Pac J Trop Biomed. 2012; 2(3): 1754-1763.

14. Lawrence R, Tripathi P, Jeyakumar E. Isolation, Purification and Evaluation of Antibacterial Agents from Aloe vera. Brazilian J Microbiol. 2009; 40: 906915.

15. Fabiny DL, Ertingshausen G. Automated ReactionRate Method for Determination of Serum Creatinine with the CentrifiChem. Clinical Chemistry.1971; 17(8): 696-700

16. Fawcett JK, Scott JE. A Rapid and Precise Method for the Determination of Urea. J Clin Pathol. 1960; 13: 156-159.
17. Cyril DG, Landry KS, Francois KYK, Abou B, Felix $\mathrm{YH}$, Timothee OA. Evaluation of Nephroprotective Activity of Aqueous and Hydroethanolic Extracts of Trema guineensis Leaves (Ulmaceae) Against Gentamicin-Induced Nephrotoxicity in rats. Int $\mathrm{J}$ Biochem Res. 2016; 15(2): 1-10.

18. Shamim S, Rana MA, Arshad N, Kumar A, Islam CN . Evaluation of Nephroprotective Extract of Leaves of Aloe barbadensis against Gentamicin induced Nephrotoxicity in Rats. Int Arch BioMed Clin Res. 2018; 4(4): 70-73.

19. Walker PD, Barri Y, Shah SV. Oxidant Mechanisms in Gentamicin Nephrotoxicity. Renal Failure. 1999. 21(3\&4): 433-442.

20. $\mathrm{Hu} \mathrm{Y}, \mathrm{Xu}$ J, Hu Q. Evaluation of Antioxidant Potential of Aloe vera (Aloe barbadensis Miller) Extracts. J Agricul Food Chem. 2003; 51: 7788-7791.

21. Kumar KV, Naidu MUR, Shifow AA, Ratnakar KS. Probucol Protects Against Gentamicin-Induced Nephrotoxicity in rats. Indian J Pharmacol. 2000; 32: 108-113.

22. Jannat N, Sultana N, Islam MR. Administration of gentamicin-induced hematobiochemical and renal morphological alterations in Swiss albino mice. African J Pharm and Pharmacol. 2017; 11(34): 426-432. 